\title{
Customer Relationship Management with Special Reference to Swathi Engineering in Chennai
}

\author{
G.Thilrukshan, J Pavithra, Sangeetha.S
}

\begin{abstract}
Today the undertaking and duties of business officials have turned out to be basically significant because of mechanical headway, expanding familiarity with individuals, developing size and multifaceted nature of business. Expanding cooperation of Govt. in the economy, rising way of life and expanding culmination There is feeling that Indian corporate business has additionally entered from economically tight market to fast moving business sector in the business condition as a rule and on account of expanding mindfulness among the purchasers, expanding rivalries in market, the investigation of purchaser conduct, in buyer items are picking up significance so as to fulfill the necessities and needs of individuals by giving right items.
\end{abstract}

This undertaking includes illustrative research for information collection.This study is based out of essential and optional research; did that would accumulate crisp information which can be broke down with the past information to look for the current patterns in retail industry. This would incorporate utilization of survey as a device for get-together data.The respondents were chosen haphazardly from the Chennai client rundown given by the organization. The examination inquiries are set to be posed to the Client associations of Swathi Engineering. Optional information for the examination has been ordered from the web sources, magazines and papers which have been useful in getting an understanding of present situation

Keywords : sociology, generalizabilit discernments

\section{INTRODUCTION}

In this advanced universe of globalization everything is evolving step by step, as development is the standard of nature. There is a huge change in purchaser's purchasing conduct too. Presently wherever shoppers are progressively cognizant about their buying. Presently they are progressively mindful and increasingly taught. Per individual pay is additionally expanding and it is the reason currently individuals are spending more. [8],[ 10], [12]
Swathi Engineering Agencies is a Proprietorship firm,formed in 1996.In the previous 15 years we have executed different undertaking like, Industrial Flooring (Epoxy/PU) To Automobile, Pharmaceutical, Fertilizer, Electronic, Leather and Chemical Industries, PU Lining To Pipe Lines For Power Stations[19],[21],[23] Atomic Plants and Infrastructure Industries, Fireproofing Of Oil Installation, LPG Storage Facilities, and Petrochemical Industries, Waterproofing For Hotels, Commercial Complexes, and Construction Industries and Builders, Anti Corrosive Coatings For Oil/Fertilizer, Petro Chemical Industries, ISRO, Etc., and Anti Corrosive Coatings for Oil/Petrochemical Industries, ISRO, Atomic Stations, Hotels Etc. [1],[3],[5]

The organization has to know the market capability of the organization so as to settle on cool headed choices on brand building. The investigation of CRMindicates the methods for fulfilling the clients in this way holding them with the organization to have long haul relationship. Consumer loyalty comprehends the dependability of the client towards the administrations rendered by the organization on floor coatings. The administration finds a conceivable method to satisfy the desires for clients and in this way pulls in new clients. The examination expects to discover the clients' fulfillment level to outline an appropriate maintenance technique of Swathi Engineering[2 ],[ 4],[6]

\section{Research DESIGN}

The design used for carrying out this research is exploratory $\&$ experience based. I intend to carry out primary and secondary research, [31],[33]carry out focus interviews and group discussions which would help me to gather fresh data which can be analyzed with the past data to seek the existing trends in service based industry. This would include usage of questionnaire as a tool for gathering data. [7],[9], [11]

Target Respondents

The respondents were selected randomly from the Chennai customer list provided by the company. The research questions are set to be asked to the 150 employees of Client organizations of Swathi Engineering. [13], [15] ,[ 17]

\footnotetext{
Revised Manuscript Received on July 22, 2019.

G.Thilrukshan, Student, Department of MBA,,Bharath institute of Higher Education \& Research,Tamilnadu,India, Email: thilrukshan@gmail.com

Ms. J Pavithra Assistant Professor ,Department of MBA,Bharath institute of Higher Education \& Research,Tamilnadu,India, Email: pavithralect@yahoo.com

Sangeetha.S Assistant Professor,Department of CSE,Bharath institute of Higher Education \& Research,Tamilnadu,India, Email: angeethasathya01@gmail.com
} 
Customer Relationship Management with Special Reference to Swathi Engineering in Chennai

Table 1:swathi engineering agencies keep their records accurately

\section{TABLE 10 SWATH ENGLEERIIG AGENCESS KEEP THEIR RECORDS ACCCRATELY}

\begin{tabular}{|c|c|c|c|c|c|}
\hline & & Frequency & Percent & Valid Percent & $\begin{array}{l}\text { Cumulative } \\
\text { Percent }\end{array}$ \\
\hline & Strondy Agree & 24 & 19.4 & 19.4 & 19.4 \\
\hline & Agee & 42 & 33.9 & 33.9 & 53.2 \\
\hline & Neutral & 47 & 37.9 & 37.9 & 91.1 \\
\hline & Disaggee & 7 & 5.6 & 5.6 & 96.8 \\
\hline & Strondy Disagee & 4 & 3.2 & 3.2 & 100.0 \\
\hline & Total & 124 & 100.0 & 100.0 & \\
\hline
\end{tabular}

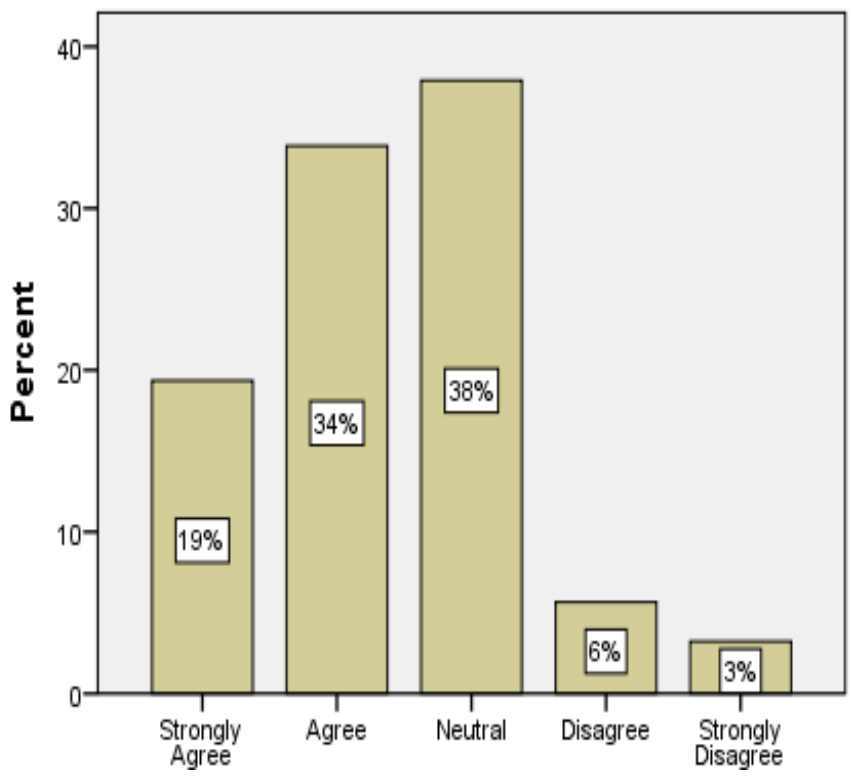

Fig 1:Responsiveness chart

Table 2: employees make information easily obtainable bycustomers
TABLE II EIPLOYEES WAKE INFORVATION EASLY OBTAINABLE BY CCSTONERS

\begin{tabular}{|l|l|l|l|l|l|}
\hline \multicolumn{2}{|l|}{} & Frequency & Percent & Valid Percent & $\begin{array}{l}\text { Cumulative } \\
\text { Percent }\end{array}$ \\
\hline \multirow{4}{*}{ Valid } & Strondy Agree & 43 & 34.7 & 34.7 & 34.7 \\
\hline \multirow{4}{*}{ Aggee } & 35 & 28.2 & 28.2 & 62.9 \\
\cline { 2 - 6 } & Neutral & 21 & 16.9 & 16.9 & 79.8 \\
\cline { 2 - 6 } & Disaggee & 20 & 16.1 & 16.1 & 96.0 \\
\hline Strongy Disagee & 5 & 4.0 & 4.0 & 100.0 \\
\hline Total & 124 & 100.0 & 100.0 & \\
\hline
\end{tabular}

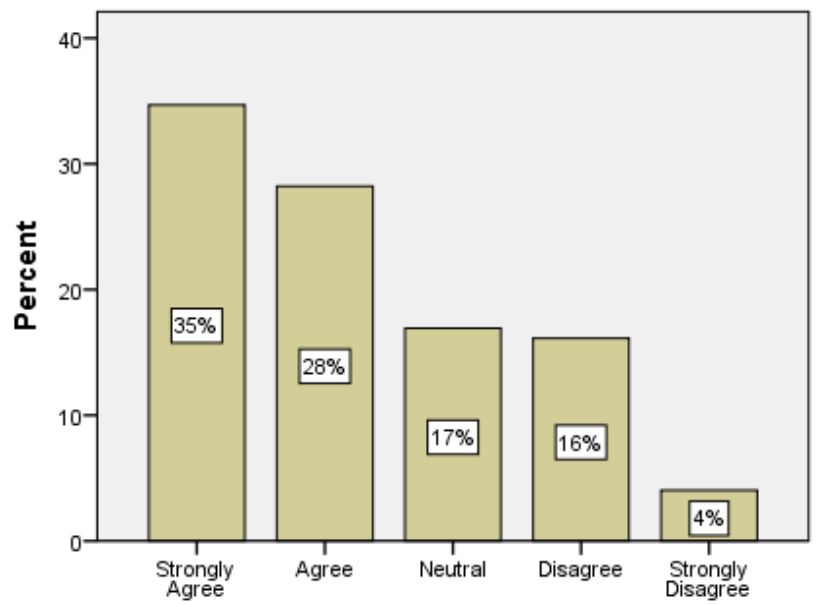

Graph 3responsiveness chart

Table 4 employees give prompt services to customers

\begin{tabular}{|l|l|l|l|l|l|}
\hline \multicolumn{2}{|c|}{} & Frequency & Percent & Valid Percent & $\begin{array}{l}\text { Cumulative } \\
\text { Percent }\end{array}$ \\
\hline \multirow{4}{*}{ Valid } & Strondyg Agee & 43 & 34.7 & 34.7 & 34.7 \\
\hline \multirow{4}{*}{ Aggee } & 36 & 29.0 & 29.0 & 63.7 \\
\cline { 2 - 6 } & Neutral & 31 & 25.0 & 25.0 & 88.7 \\
\cline { 2 - 6 } & Disagee & 5 & 4.0 & 4.0 & 92.7 \\
\cline { 2 - 6 } & Strongly Disagee & 9 & 7.3 & 7.3 & 100.0 \\
\hline & Total & 124 & 100.0 & 100.0 & \\
\hline
\end{tabular}




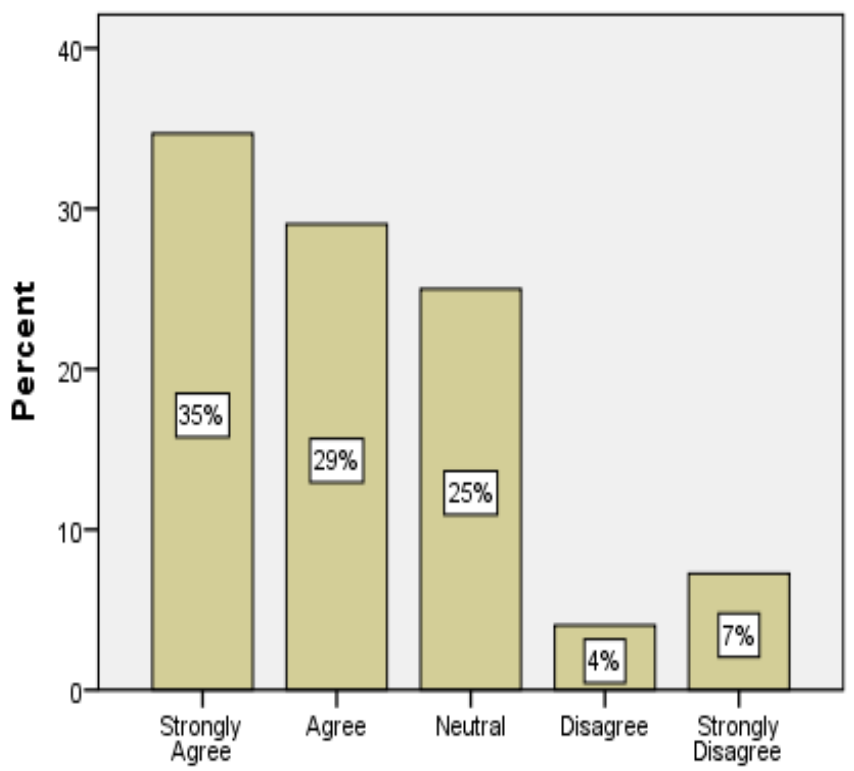

TABLE 7 Employees Are Never Too Busy To Respond To Customers Requests

\begin{tabular}{|c|c|c|c|c|c|}
\hline & & Frequency & Percent & Valid Percent & $\begin{array}{l}\text { Cumulative } \\
\text { Percent }\end{array}$ \\
\hline & Strondy Aggee & 27 & 21.8 & 21.8 & 21.8 \\
\hline & Aggee & 33 & 26.6 & 26.6 & 48.4 \\
\hline & Neutral & 51 & 41.1 & 41.1 & 89.5 \\
\hline & Disagyee & 11 & 8.9 & 8.9 & 98.4 \\
\hline & Strongdy Disaggee & 2 & 1.6 & 1.6 & 100.0 \\
\hline & Total & 124 & 100.0 & 100.0 & \\
\hline
\end{tabular}

Fig 4:responsiveness chart

Table 5 employees are always willing to help customers

\begin{tabular}{|l|l|l|l|l|l|}
\hline \multicolumn{2}{|c|}{} & Frequency & Percent & Valid Percent & $\begin{array}{l}\text { Cumulative } \\
\text { Percent }\end{array}$ \\
\hline \multirow{5}{*}{ Valid } & Strongly Agree & 41 & 33.1 & 33.1 & 33.1 \\
\cline { 2 - 7 } & Agree & 12 & 9.7 & 9.7 & 42.7 \\
\cline { 2 - 7 } & Neutral & 45 & 36.3 & 36.3 & 79.0 \\
\cline { 2 - 6 } & Disagree & 25 & 20.2 & 20.2 & 99.2 \\
\cline { 2 - 6 } & Strongly Disagree & 1 & .8 & .8 & 100.0 \\
\cline { 2 - 6 } & Total & 124 & 100.0 & 100.0 & \\
\hline
\end{tabular}
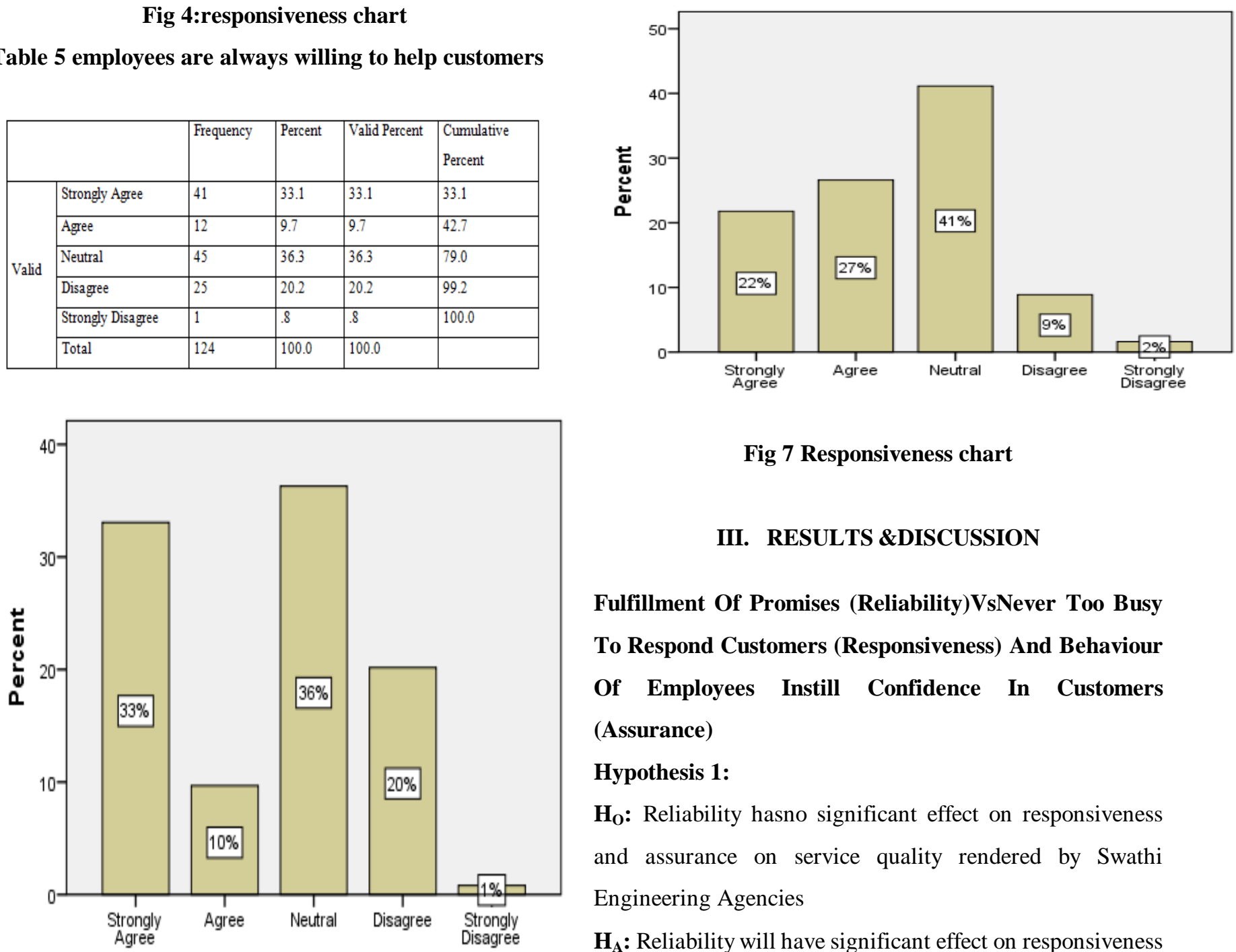

Fig 7 Responsiveness chart

\section{RESULTS \&DISCUSSION}

Fulfillment Of Promises (Reliability)VsNever Too Busy To Respond Customers (Responsiveness) And Behaviour Of Employees Instill Confidence In Customers (Assurance)

\section{Hypothesis 1:}

$\mathbf{H}_{\mathbf{O}}$ : Reliability hasno significant effect on responsiveness and assurance on service quality rendered by Swathi Engineering Agencies

$\mathbf{H}_{\mathrm{A}}$ : Reliability will have significant effect on responsiveness and assurance on service quality rendered by Swathi Engineering Agencies

Fig 6 Responsiveness chart

Hypothesis 2:

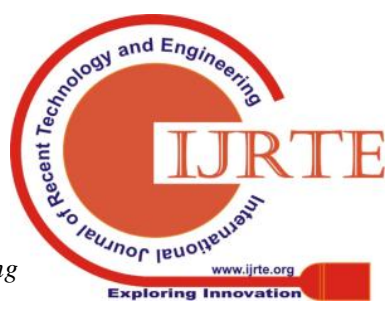


$\mathbf{H}_{\mathbf{O}}$ : Reliability hasno significant effect on responsiveness

\section{Hypothesis 3:}

$\mathbf{H}_{\mathbf{O}}$ : Reliability hasno significant effect on assurance on service quality rendered by Swathi Engineering Agencies

$\mathbf{H}_{\mathbf{A}}$ : Reliability will have significant effect on assurance on service quality rendered by Swathi Engineering Agencies

\section{Table 8:Annova table}

\section{ANOVA TABLE}

\begin{tabular}{|l|l|l|l|l|l|}
\hline \multicolumn{5}{|l|}{ Tests of Betreen-Subjects Effects } \\
\hline Dependent Vaniable: promise \\
\hline Source & $\begin{array}{l}\text { Type III Sum of } \\
\text { Squares }\end{array}$ & df & Mean Square & F & Sig. \\
\hline Corrected Model & $18.834^{\mathrm{a}}$ & 18 & 1.046 & 1.175 & .295 \\
\hline Intercept & 292.128 & 1 & 292.128 & 327.984 & .000 \\
\hline Nevertoobusy & 4.991 & 4 & 1.248 & 1.401 & .239 \\
\hline Behaviour & 4.534 & 4 & 1.134 & 1.273 & .285 \\
\hline Nevertoobusx. ${ }^{*}$ behaviour & 8.231 & 10 & .823 & .924 & .514 \\
\hline Eror & 93.521 & 105 & .891 & & \\
\hline Total & 1012.000 & 124 & & & \\
\hline Corrected Total & 112.355 & 123 & & & \\
\hline a. R Squared =.168 (Adjusted R Squared $=.025$ ) & & & & \\
\hline
\end{tabular}

\section{Results:}

$\mathrm{P}=0.239>0.05$

Accept null hypothesis, hence reliability hasno significant effect on responsiveness

$\mathrm{P}=0.285>0.05$

Accept Null Hypothesis, reliability hasno significant effect on assurance on service quality rendered by Swathi Engineering Agencies[26],[28],[30]

Gender \& Marital Status $(\mathrm{P})=0.514>0.05$

Accept Null Hypothesis; hence the combination of reliability hasno significant effect on responsiveness and assurance on service quality rendered by Swathi Engineering Agencies[14],[ 16], [18]

\section{CONCLUSION}

As of late the significance of relationship quality in modern infra associations have progressively underlined by the two specialists and professionals in light of the general conviction about relationship promoting endeavors upgrading associations with clients. So in this examination, the analyst intended to uncover the impacts of relationship quality measurements on clients' fulfillment and suggestion conduct. The investigation utilized a 6 quality measurement factors to evaluate builds identified with relationship quality impacts on fulfillment and suggestion. The outcomes demonstrated that builds about relationship quality is by all accounts great at Swathi Engineering Agencies.

\section{REFERENCES}

1) BharthVajan R., Ramachandran S.,Psychographic dimensions of training,2016,International Journal of Pharmacy and Technology,V-8,I-4,P-23727-23729
$\mathbf{H}_{\mathbf{A}}$ : Reliability will have significant effect on responsiveness

2) Balakrishnan P., Bharthvajan R.,A study on human resource planning in hospitals in Chennai City,2014,International Journal of Applied Engineering Research,V-9,I-22,P-7503-7507

3) Priyadarsini P., Bharthvajan R.,Role of emotional intelligence training programme in reducing the stress of the nurses,2014,International Journal of Applied Engineering Research,V-9,I-22,P-7411-7421

4) Kerinab Beenu G., Bharthvajan R.,Empirical analysis on the cosmetic buying behavior of young women in South India,2014,International Journal of Applied Engineering Research,V-9,I-22,P-7361-7366

5) Balakrishnan P., Bharthvajan R.,Whistling in the wind,2014,International Journal of Applied Engineering Research,V-9,I-22,P-7586-7593

6) Krishnan B., Peter M.,Health hazards of Indian Bpo employee-an alarming issue, 2014,International Journal of Applied Engineering Research,V-9,I-22,P-7336-7341

7) Kerinab Beenu G.H., Peter M.,Role of insurance in economic development,2014,International Journal of Applied Engineering Research,V-9,I-22,P-7532-7539

8) Balakrishnan P., Peter M., Priyadarsini P.,Efficiency of safety measures for wellbeing of employees in manufacturing industry,2014,International Journal of Applied Engineering Research,V-9,I-22,P-7376-7382

9) Anbarasi M., Praveen Kumar S.,Online sales promotions of herbal products and its effectiveness towards tanisha.com,2019,Indian Journal of Public Health Research and Development,V-10,I-1,P-195-200

10) Anbarasi M., Praveen Kumar S.,Various online marketing and promotions strategies to improve the validation towards the organic products in the pharmaceutical sectors, 2019,Indian Journal of Public Health Research and Development, V-10,I-1,P-263-269

11) Loganathan R., Praveen Kumar S.,Grievance handling a key factor for solving issues of employees in an organization,2014,International Journal of Applied Engineering Research,V-9,I-22,P-7483-7491

12) Loganathan R., Praveen Kumar S.,Study on preference of private label brands in super and Hypermarkets,2014,International Journal of Applied Engineering Research,V-9,I-22,P-7327-7335

13) Smitha M., Praveen Kumar S.,Understanding stress and its managementamong the nurses in Chennai city,2014,International Journal of Applied Engineering Research,V-9,I-22,P-7560-7565

14) Kerinab Beenu G.H., Praveen Kumar S.,A study on the investment behavior of Chennai investors in mutual fund schemes,2014,International Journal of Applied Engineering Research,V-9,I-22,P-7520-7525

15) Loganathan R., Praveen Kumar S.,Retention strategies key for organizational productivity,2014,International Journal of Applied Engineering Research,V-9,I-22,P-7443-7447

16) Pavithra J., Ganesan M., Brindha G.,State wise analysis of microfinance sector in India,2016,International Journal of Pharmacy and Technology,V-8,I-4,P-23417-23432

17) Pavithra J., Ganesan M.,A comparative study on microfinance in India and abroad,2016,International Journal of Applied Business and Economic Research,V-14,I-8,P-5471-5476

18) Pavithra J., Ganesan M.,A study on awareness and impact of micro-financial schemes,2016,International Journal of Applied Business and Economic Research,V-14,I-8,P-5449-5460

19) Senthilmurugan P., Pavithra J.,Consumer preference towards organised retailing with reference to Big Bazaar,2014,International Journal of Applied Engineering Research,V-9,I-22,P-7469-7475

20) Senthilmurugan P., Pavithra J.,Implication of social media marketing in growing healthcare industry,2014,International Journal of Applied Engineering Research,V-9,I-22,P-7448-7456

21) Loganathan R., Pavithra J.,Consumer perception towards private label brand over other brands in super markets and hypermarkets,2014,International Journal of Applied Engineering Research,V-9,I-22,P-7355-7360

22) Kerinab Beenu G., Pavithra J.,Tradeâ€"off between liquidity and profitability in logistics industry,2014,International Journal of Applied Engineering Research,V-9,I-22,P-7398-7401

23) Kerinab Beenu G., Pavithra J.,A study on the prospective consumerâ€ $€^{\mathrm{TM}_{S}}$ perception towards utility cars in Chennai city,2014,International Journal of Applied Engineering Research,V-9,I-22,P-7526-7531

24) Pavithra J., Dilli Babu P., Ambuli T.V.,A study on budgetary control at Maruti Service Masters, Chennai,2014,International Journal of Applied Business and Economic Research,V-12,I-2,P-151-161

25) Pavithra J., Dilli Babu P., Ambuli T.V.,A study on customer satisfaction of retro Garments Pvt Ltd, Chennai,2014,International Journal of Applied Business and Economic Research,V-12,I-2,P-381-391

26) Kerinab Beenu G.H., Pavithra J., Senthilmurugan P.,A study on the influence of promotional activities for TATA ARIA among consumers in Chennai,2014,International Journal of Applied Engineering Research,V-9,I-22,P-7572-7578

27) Vijayaragavan S.P.,An investigative expert that's general FBG sensors,International Journal of Mechanical Engineering and 
Technology,V-8,I-8,PP-1500-1505,Y-2017

28) Vijayaragavan S.P.,Equalization routing protocol for Wi-Fi sensor strategy,International Journal of Mechanical Engineering and Technology,V-8,I-8,PP-1662-1666,Y-2017

29) Karthik B., Kiran Kumar T.V.U., Vijayaragavan P., Bharath Kumaran E.,Design of a digital PLL using $0.35 \mathrm{I}^{1} / 4 \mathrm{~m}$ CMOS technology,Middle East Journal of Scientific Research,V-18,I-12,PP-1803-1806,Y-2013

30) Kanniga E., Selvaramarathnam K., Sundararajan M.,Kandigital bike operating system,Middle - East Journal of Scientific Research, $\mathrm{V}$

31) Jasmin M., Vigneshwaran T., Beulah Hemalatha S.,Design of power aware on chip embedded memory based FSM encoding in FPGA,International Journal of Applied Engineering Research,V-10,I-2,PP-4487-4496,Y-2015

32) Jasmin M.,Optimization techniques for low power VLSI circuits,Middle East Journal of Scientific Research,V-20,I-9,PP-1082-1087,Y-2014

33) Jasmin M., Vigneswaran T.,Fuzzy controller for error control of on - Chip communication,2017 International Conference on Algorithms, Methodology, Models and Applications in Emerging Technologies, ICAMMAET 2017,V-2017-January,I-,PP-1-5,Y-2017

\section{AUTHORS PROFILE}

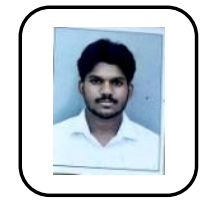

Student, Department of MBA,,Bharath institute of Higher Education \& Research,Tamilnadu,India,

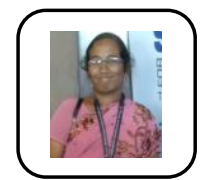

Ms. J Pavithra Assistant Professor,Department of MBA,Bharath institute of Higher Education \& Research,Tamilnadu,India,

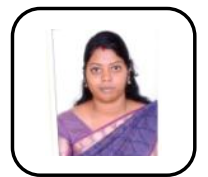

Sangeetha.S Assistant Professor,Department of CSE,Bharath institute of Higher Education \& Research,Tamilnadu,India, 